\title{
Rule of Law and Constitutionalism in Nigerian Democracy: A Critical Relativism Discuss in the Context of International Law
}

\begin{abstract}
By Isaac O. C. Igwe*
The synthesis of rule of law enthrones democracy, justice and goes with such characteristics as liberty, freedom, and the restoration of the dignity of man. The rule of law is predicated upon absolute autonomy being accorded to the judicial arms of the government of any society, state, or country. Thus, the application and interpretation of the law must be under the control of impartial courts adjudicating within the ambit of fair judicial procedures. The dialectics of power and the guiding principles of governance are anchored in the constitution which enshrines the provisions of enforceable laws. The law is the cardinal power of a nation, a direction for due process, and a guiding principle for good governance. The age of enlightenment and the middle ages have a special place for the rule of law as opposed to tyranny otherwise, life could have been chaos. The role of law cannot be left in isolation of democracy as both are interlaced as core universal principles of the civilised world. This paper will explore the rule of law as a paramount factor in constitutionalism, idealism, and realistic principles of the law of any given society. The treatise will in general terms discuss the principles of rule of law and articulate it with the hitherto Nigerian democracy. It will conclude with the argument that complete independence of the judiciary in Nigeria is paramount to ensure proper implementation of rule of law for a better Nigeria.
\end{abstract}

Keywords: Rule of Law; Constitutionalism; Independent Judiciary; Tyranny; Nigerian Democracy. Rule of Law;

\section{Introduction}

Essentially, rule of law is a cornerstone of present-day constitutional democracy. ${ }^{1}$ The nomenclature rule of law is interrelated to constitutionalism. ${ }^{2}$ Nonetheless, the concept and conception of 'rule of law' is fluid, means different things to different people, and varies from one place to another and from one period of time to another. ${ }^{3}$ In the array of values of liberal political morality, the Rule of Law is one ideal that predominates over other values such as democracy, social justice, economic freedom, and human rights. Evaluating this plethora of values, legal philosophers such as $\mathrm{Raz}^{4}$ have emphasised the need to differentiate

*LLB (Hons), Barrister \& Solicitor Supreme Court of Nigeria, LLM, Ph.D. (Law), Birkbeck, University of London, London, UK. Email: isaacigwe@ hotmail.com.

${ }^{1}$ See Ferioli (2015).

${ }^{2}$ See Ten (2017).

${ }^{3}$ See William (2020).

${ }^{4}$ See Raz (1977). 
the rule of law from other values. As a matter of analytical clarity, they limit the priority of rule of law to formal and procedural angles of governmental institutions and not the substantive policies they administer. The rule of law applies not only to the government but also to citizens, who should respect and adhere to legal norms whether they agree with them or not. In instances where their interest conflicts with others, they should accept the legal determinations as these pertain to their rights or duties. The rule of law requires the law to be uniform for everyone; no one is above the law and everyone has access to the law's protection. In these generalities, the dialectic of the rule of law per se is a controversial idea. It has been contrasted with the 'Rule of $\mathrm{Men}^{15}$ and distinguished from the rule of legislation, ${ }^{6}$ identifying the rule of law as the gradual development of common law. The application of this concept in any society promotes not only peace among the citizens but economic, social, and political security. Whilst the absence of the rule of law can breed despotism, dictatorship, lawlessness, anarchy, or absence of checks and balances of power within the three arms of government which can destabilise the structural framework of the government. ${ }^{7}$ The concentration of power in one pair of hands or a group is, to say the least, dangerous, since "Power corrupts and absolute power corrupts absolutely. ${ }^{\prime 8}$ Suffice to say that the greater the power, the more dangerous the abuse. ${ }^{9}$ The rule of law is a system for preventing the abuse of power by individuals or government discretionary powers. It affords the court the power to direct the government to rule within the principles of the law and for both citizens and their government to be bound by the Orders of the Courts. ${ }^{10}$ The concept of rule of law presupposes that a society should be governed by the law. This ordinarily refers to the impact and authority of law within the society, especially as a curtailment of individual citizens' activities, as well as those of government officials. The current unlawful detention of Nigerians against the rule of law, against court Orders, is not only contrary to legality but against the universal values of Human Rights. A Country without respect for the rule of law is not only primitive but uncivilised. It is undeniable that the rule of law is intertwined with the independence of the judiciary since the constitutional responsibility of upholding the principles of rule of law is within the watch of the judiciary. It cannot be overemphasised that the independence of the judiciary must be supported and kept separate from any undue interference of the government in keeping with the doctrines of separation of powers. That is the spirit of democracy as a model to check arbitrary power, corruption, or unlawful activities. The principal idea of the rule of law is that the law is supreme, no one is above the law and law applies equally to all ruled and rulers. It ensures a 'government of law' and not a 'government of men. ${ }^{11}$ Thomas Paine wrote in his book 'Common Sense' the Principles and the essence of the rule of law when he stated that:

\footnotetext{
${ }^{5}$ See Aristotle.

${ }^{6}$ See Hayek (1972).

${ }^{7}$ See Acholonu (1995).

${ }^{8}$ See Dalberg-Acton (1910). .

${ }^{9}$ See Burke (1771).

${ }^{10}$ See Burke (1771) at 43-47.

${ }^{11}$ See Gaynor (1903).
} 
"[...] the world may know that so far as we approve of monarchy, that in America THE LAW IS KING. For as in absolute governments the king is law, so in free countries, the law ought to be King; and there ought to be no other." ${ }^{\prime 2}$

Thomas Paine's intent and purpose here was to demonstrate the supremacy of the Law above all persons and authority, no matter your position in the society, political or ecclesiastical. The nomenclature 'Rule of Law' has been widened in the scope above the classic formulation articulated by A.V. Dicey and has extended to the supremacy of the constitution, the supremacy of the law, including the placing of court decisions above all persons and governments. It has also spread its tentacles to the independence of the Judiciary; the right to personal liberty and keeping to the tenets of democratic values, freedom of the press, and freedom of association, including free and fair elections. ${ }^{13}$ The opposite of the rule of law is arbitrary government. In like manner, the rule of law introduces the relationship between the government and the people. That is why John Locke says that "wherever law ends, tyranny begins. ${ }^{\text {"14 }}$ The rule of law applies to both private and public officials and covers their conduct and behaviour. Apart from the fact that no one is above the law under the rule of law, it is trite that the sub principles of the rule of law are that the law is always applied and that the legal redress is always through the courts. The rule of law is a complex principle made up of collections of subprinciples. It is difficult to ascertain how far the law rules Nigeria and in most cases can be likened to a 'noble lie $^{15}$ to the Nigerian constitution. ${ }^{16}$

The Nigerian institution of governance is weak and constructed around individual leaders who have malign intentions for self-enrichment of themselves, their families, and even generations unborn. This intention metamorphosed into corruption, abuse of power, poor leadership, judicial ineptitude, and flagrant disrespect to the rule of law or due process. One of the greatest challenges in the Nigerian governance structure is government by mediocrity. Most of the past and present Nigerian leaders are either illiterate, half-baked educated leaders or educated illiterates. The leadership of mediocrity has to be replaced with a government of enlightenment. There has to be an intellectual movement emphasizing individualism rather than tradition. The Nigerian governance structure needs to be overhauled to reflect the age of enlightenment in consonance with the importance of science and reason, instead of religion, tradition, tribe, or ethnic sentiments. This was massively impacted by 17th-century philosophers such as John Locke, Immanuel Kant, Jean-Jacques Rousseau, Adam Smith, Rene Descartes, Isaac Newton, Johann Wolfgang von Goethe, etc. Countries like England, Europe, Canada, Switzerland, Singapore, the United States of America,

\footnotetext{
${ }^{12}$ See Paine (1776) at 49.

${ }^{13}$ See Anifowose \& Enemuo (1999) at 151.

${ }^{14}$ See Locke (1988).

${ }^{15}$ Noble Lie- Originated from Plato's Republic, Book 111. Noble lie to Plato is a myth or untruth propagated by leaders to maintain social harmony or to strengthen an agenda. It represents a political deception or political lies. Plato's scepticism was hyped especially concerning human nature and the volatility of man's policy to laws. See Taylor \& Kraut (1977).

${ }^{16}$ See Harden \& Norman (1988).
} 
and other civilised worlds to mention but a few, do well economically, advanced in respect for the rule of law and stable government because they are governed by well -educated civilised leaders. The education we know is power. Nelson Mandela said that: "Education is the most powerful weapon which you can use to change the world."17 He further said that: "The power of education extends beyond the development of skills we need for economic success. It can contribute to nation-building and reconciliation. "A good head and good heart are always a formidable combination. But when you add to that a literate tongue or pen, then you have something very special. ${ }^{\prime \prime 18}$

Nonetheless, Nigeria has so many well-educated people both at home and abroad that can take up the leadership position and reform the governance system with strict implementation of the rule of law, except that the governance process is not about election, but a selection of individuals into power through lobbying and elite corrupt leadership conspiracy. It is a far cry to expect an individual who is illequipped in the art of governance or in-exposed to human relations, economics, diplomacy, law, or international relations to govern a complex multicultural country like Nigeria. A solid governance structure with strict adherence policy to the rule of law should be put in place and the right people should be allowed into the government of Nigeria. Otherwise, one should not put something on nothing and expect it to stand, because, it will surely collapse. ${ }^{19}$ God did not make any mistake allowing biblical Moses to be brought up by the Pharaohs of Egypt who were then one of the most enlightened powerful ruling families in the world. God must have known that one day Moses will lead his people to the promised land of Canaan in Israel. It could be argued that what aided Moses in his leadership was his exposure to a good education, sound civilisation, general knowledge, skills, and technical know-how. This paper will examine the concept of "rule of law" and separation of powers with the independence of the judiciary in a democratic government. This article will further explore the supremacy of the rule of law and articulate its constitutionalism, idealism, and realism in a democratised society with particular emphasis on the Nigerian government. Finally, the writing will postulate some recommendations on the way to achieve complete independence of the judiciary for a democratised Nigeria.

\section{Overview of Nigerian Democracy}

It could be argued that the beginning of Nigeria's democracy dates back to 1914 when the Northern and southern regions of Nigeria were allowed by the British colonialists to govern themselves. This marked the first time a Nigerian governed in a Nigerian government for Nigerians. In contemporary Nigerian society, though Nigeria is practicing democracy, it is not yet up to the standard experienced in advanced countries like the United States of America, Canada, England, or Europe. That is why Sagay stated that: "Democracy in Nigeria is still

\footnotetext{
${ }^{17}$ See Mandela (1990).

${ }^{18}$ Ibid.

${ }^{19}$ See MacFoy v United Africa Company Limited (1961).
} 
'fledge', 'nascent', and 'young' and that it needs to be properly nurtured"20 The author is trying to say that democracy is incomplete without the proper application of the rule of law, which is the cream of democracy. It is only when the law is supreme that individual freedom and liberty will be safeguarded and no single individual or government power will dominate the political system. That is the time the Nigerian democracy will become mature and attain the standard of a free society. Nigeria after 60 years of independence still struggles between democracy and military dictatorship which in the past usually topple the existing democratic government through military coup as a corrective measure. Paradoxically, the military government ends up lasting longer in power than the democratic government they came to "correct." The question now is whether the intervention is corrective or a bastardisation of the democratic process. ${ }^{21}$ The military coup sometimes comes with a deep confusion, colossal loss of lives, loss of resources, destruction of infrastructure, and properties of citizens. Military intervention is never in the interest of individual citizens. It is autocratic or dictatorial and intended to establish leadership by selection as opposed to the election. At best, a coup de ta that ousted a democratic rule is not a democracy, but a liberalised autocracy. The author is not in any way excusing the democratic election and practices in Nigeria which apparently may justify the military intervention. Nonetheless, the democratic process in Nigeria is bedevilled with corruption, undemocratic with rampant assassinations, thuggery, intimidation, rigging, harassment, and other electoral vices. ${ }^{22}$ The democratic process also encourages selection, not election because a particular recycled set of politicians are the ones in power. Sometimes, these recycled politicians are called "the Cabal". It is hardly possible for a new face in politics to emerge as a leader or be appointed into an esteemed governmental position unless that person has a godfather in government or has paid the dues or belongs to a special group, family, or sect. As a result of these, it undermines the full operation of the law against some people who are now regarded as white elephants. This brings about the suppression of the weight of the law upon some people and leads to them violating the orders of the court with flagrant disrespect to the rule of law. Some of these over recycled political leaders are careful to the extent they use the full force of the law on certain individuals of the same class for fear of being implicated in their past tomfoolery or atrocity as they also do have some skeletons in the cupboard. In this circumstance, the operation of the rule of law is highly impaired and the door to dictatorship is widely opened. To this end, a great deal of the Nigerian population is disillusioned in the electoral process and more inclined to absent themselves from the electoral process which results in the imposition of the will of the minority over the will of the majority. This system is cancerous and has eaten deep into the fabrics of Nigerian society and must be resisted, changed, or stopped literarily through a surgical operation. The standard of governance in Nigeria is not yet in the realm of strict observance of the rule of law and the absence of observing rule of law is an aberration. Where rule of law reigns, corners are not cut in

\footnotetext{
${ }^{20}$ See Sagay (1996).

${ }^{21}$ See Sagay (1996) at 529.

${ }^{22}$ See Ome (2011).
} 
governance, and justice is maintained. The adherence to the rule of law strengthens the operation of each organ of government and guides them to operate within the roles created by law without usurping the roles of other organs of the government. In so doing, there will be peace among the organs and minimal frictions. The theoretical ideals of the rule of law propounded by Dicey are opposed to the Nigerian governance system which subjugates rule of law, inclined to rule by man or absolute authority by the man that breeds arbitrary powers against the citizens. At present, different law applies to different classes of the population, and these laws are not administered by courts but by a minority of powerful individuals. Automatically, the interpretation and enforcement of the laws which are the exclusive reserve of the courts are taken away.

Ideally, one of the core features of democracy is adherence to the rule of law through the institution of independence of the judiciary. The rule of law could be defined as the minimisation of executive powers of the state about a country's constitution and laws formed by the majority. ${ }^{23}$ This simply means a government of laws, not men' popularised by John Adams, the second President of the United States. ${ }^{24}$ It implies the supremacy of the law over and above the authority of any individual and connotes overriding checks on political power, state power against individual rights. Fundamentally, the State's power must be regulated by a system of laws, procedures, judicial precedents, and judgments to ensure the survival of democracy. Let us take a cue from some foreign countries like Germany, Singapore, and Switzerland that have an existing strong rule of law. This makes their business both local and foreign to grow, people feel free to walk around any time without fear of getting mugged, raped, or killed. By and large, with rule of law solidly in place, the economy will be booming, the country will be safe, the foreign inflow of investment attracted, tourism will be improved and quality of life will be enhanced. The strong presence of rule of law in Nigeria can transform it from a third-world country to a first world. Admittedly, Nigerian experience both in the military and democratic administration is the opposite as its successive leadership often has infringed this concept with impunity. The outcry of its citizens to the government's flagrant carelessness and incautious attitude to the concept of rule of law has often fallen on deaf ears. Unless these existential shenanigans are properly addressed and implemented within Nigerian polity, the country can at best be described as an undemocratic enclave. It is a far cry to say that there is a judicial Independence in Nigeria where other arms of government especially the executive publicly criticises the courts, intimidates them, or in extreme cases put some judges under house arrest or give orders through their aids to physically drag serving judges out of their houses. ${ }^{25}$ This defeats the sacredness of the seat of judges in the temple of justice, ordinarily created to be feared as an oracle of justice of any country. The constitution should have a major impact on the judicial system. It is wrong for the power of the President to override due process as the constitution tends to grant him a lot of powers. As a result of such absolute power, he can set aside any provisions of the law if he likes. This has nothing to do with

\footnotetext{
${ }^{23}$ See Diamond (1988) at 4.

${ }^{24}$ See Handlin \& Hadlin (1966).

${ }^{25}$ See Onyekwere \& Onochie (2019).
} 
executive powers and immunity, but there must be checks and balances to avoid tyranny. It appears that the institutions of governance are built around individual leaders and that truncates the proper functioning of the government process independently outside prevailing political corruption, judicial ineptitude, weak leadership, abuse of power, and absence of due process. ${ }^{26}$ In the words of former Secretary-General of the United Nations, Mr. Kofi Annan:

"Corruption is an insidious scourge that impoverishes many countries and affects all. It discourages foreign investments and hinders economic growth. It is a major obstacle to political stability and the successful social and economic development of any nation. ${ }^{\prime 27}$

Realistically, the solution should be centered on policies that will empower institutions of governance in such a manner that will be extremely difficult for an individual leader to manipulate them.

\section{Independence of the Judiciary}

One fundamental principle of law is that the Judges must be impartial and non-political. Fundamentally, it is important to differentiate between liberal democratic countries and authoritarian regimes. In a liberal democratic country, authority of the law is not influenced by the political regime in power and thereby presupposes that the government is non-political. In such countries, laws are interpreted by independent Judges. Judicial independence is the key factor in upholding the rule of law. Such independence must be guaranteed under the constitution and government officials must keep to this responsibility. To uphold justice, the independence of the judiciary should not only be free from government interference but should be respected. Otherwise, the judges might be inclined to work in favour of the government resulting in injustice. Where there is no illicit relationship between the judges and the government, there will not be any possibility of kick-backs or financial gratifications from the government to judges which can influence them to act in favour of the government. Conversely, in an authoritarian regime, the courts could become an instrument of the state. This was exemplified in the 1930s Soviet Union where judges applied "Social legality" as termed. These are organised show trials used against political opponents to expose and punish them. Generally, in Nigeria, independence of the judiciary is always under pressure because of political judicial decisions. Substantively, the appointment process of the members of the judiciary affects the independence of the judiciary. Those appointments are controlled by the President ${ }^{28}$ and as long as the position of the head of the judiciary is fused with that of the Chief executive of the country, the role of the judges is under the whims and caprices of the person

\footnotetext{
${ }^{26}$ See Efebeh (2015).

${ }^{27}$ See United Nations (2004).

${ }^{28}$ See the Constitution of the Federal Republic of Nigeria, 1999, as amended. Chapter 7 , Section 231 (1).
} 
that put them in office and the independence of the judiciary appears a mere constitutional fiction. The Judiciary according to Black's Law Dictionary is "The branch of government responsible for interpreting the laws and administering justice. ${ }^{\prime 29}$

The outcome of the interpretation of the law is justice. The powers of the judiciary in Nigeria are enshrined in Section 6 of the Constitution of the Federal Republic of Nigeria 1999 (as amended). Among the three arms of government, the Executive, the legislature is elected into office, while the judiciary is not elected into office by the electorates but appointed. The Magistrates, the Judges, and justices representing the judicial members are appointed and this makes their position vulnerable because they can be hired and fired. Separation of powers is the fundamental feature of a democratic government. It was introduced by Baron de Montesquieu to protect citizens from dictatorship. It is the intent of Section 6 of the Nigerian Constitution that the judiciary shall be poised to take every case brought before it unless on grounds of conflict of interest. The judiciary should not pick and choose political cases on the unknown pretext of being led to be corrupt. ${ }^{30}$ The Judiciary in the interest of justice should resist corruption and fight any act that will make the public believe that its authority is used to cover criminality or corruption. They should always be guided by the comments of Hon. Justice Niki Tobi, that:

"A judge who takes bribes is not only a criminal who should be prosecuted, he is also a sinner who is for eternal condemnation [...] The bench is not a place to make money, it is a place to make a name. ${ }^{131}$

The judiciary is the arm of government that checks and directs the other arms of government as the last hope of the common man. ${ }^{32}$ As the court is the last hope of both the common and uncommon man, it beholds on the judges to eschew corruption since corruption is the antithesis of the judicial office which is supposed to be integrity-driven, sustained by respect. They must live above board like Caesar's wife because they hold power over 'life and death. ${ }^{33}$ The judiciary is the last hope of the common man arguably means that the court is the only place where the common man can get justice. In circumstances where there is a dispute between two parties and they cannot settle it between themselves, among their kinsmen or mediators, they can run to the court as the last resort for legal remedies. That is why the judiciary's function is to interpret the law and not to

\footnotetext{
${ }^{29}$ See Garner (2004).

${ }^{30}$ See Egbewole (2011).

${ }^{31}$ See Ani (2021).

${ }^{32}$ See Egbewole (2013).

${ }^{33}$ People who are involved with a famous or prominent figure should avoid attracting negative attention to themselves, rather, they should exude exemplary ethics. The wife of a Roman emperor is presumed to be above fault; if her character is suspicious, it could negatively impact on the husband's image, political or social strength. That phrase "Caesar's wife must be above suspicion" was claimed to have been used by Julius Caesar to defend why he divorced his wife, Pompeia.
} 
twist the truth or distort facts. ${ }^{34}$ The result of the interpretation of the law is justice. The court is like a holy sanctuary where both the common and uncommon man resort to if there is any wrong done to them. The role of the judiciary in the government of Nigeria presupposes that the judiciary is not corrupt. This assertion cannot be conclusive as in any twelve, there must be a Judas. There has been an incidence of corruption of judges which has opened criticisms from the judiciary, academics, and intellectuals. Professor Itse Sagay said: "judges who are corrupt have destroyed the judiciary and nothing is too much for their punishment."

Hon. Justice Mahmud Mohammed added on 7th November 2016 on the Occasion of swearing-in of two justices of Supreme Court that: "You must remain blind to personality and status, and remain the hope of all men whether common or uncommon." 35

Whilst Hon. Justice Samson Uwaifo stated that: "A corrupt judge is more harmful to the society than a man who runs amok with a dagger in a crowded street." 36 The National Judicial Council ("NJC"), a body responsible for the approval of the Chief Justice of Nigeria ("CJN"), operations must be checked as power corrupts and absolute power corrupts absolutely.

Consequently, Harry Truman has this to say, "there is a lure in power, it can get into a man's blood just as gambling and lust for money have been known to do. ${ }^{137}$ Ordinarily, the judges are sworn to be impartial in the application of the law to protect the interest of the citizens. That is why the emphasis that the judiciary is the last hope of the common man resonates in the legal profession. Instead, the appointment process of the members of the judiciary especially the Chief justice of the Federation, justices, Grand Khadi, and the Attorney General of the federation through the Nigerian Judicial Council ("NJC"), weighted by the President, influence their independence and impartiality in dispensing justice or adjudication on matters of state interest in the court. Potentially, in such circumstances, they become unduly loyal to the President, the ruling political party, and somehow fell in the expected principles of non - political and impartiality. One cannot say that the Nigerian government is keeping to the tenets of independence of the judiciary as there has been evidence of usurpation of power from one tier of government to another. The recent unceremonious removal of the Chief Justice of Supreme Court of Nigeria $(\mathrm{CJN})$, Justice Walter Onnoghen by President Mohamadu Buhari arguably is a concern for the healthy growth of Nigerian democracy and the Judiciary. The CJN was indicted on a Six count charge of "omitting or failure to declare" certain named assets and false declaration of assets dated 10 January 2019. Justice Onnoghen (CJN) denied allegations of asset declaration fraud which is the vexed issue before the Code of Conduct Tribunal (CCT) but admitted to having forgotten to declare some assets. President Buhari said that the CJN admission is enough to remove him from office considering his status as an officer of the Court. Mr. President said that the CJN should not rely on the claim that he forgot, as ignorance is not a defence in law and thus on the 25th January 2019,

\footnotetext{
${ }^{34}$ In some cases, the judiciary makes law by way of "Judicial Precedent."

${ }^{35}$ See Agunkwu (2017).

${ }^{36}$ See Ani (2021).

${ }^{37}$ See Gibbs \& Duffy (2012).
} 
removed the CJN by ex parte order of the $\mathrm{CCT}{ }^{38}$ Persuasive as the President's argument may seem, but has the due process been observed and followed by the constitution of the Federal Republic of Nigeria? Has the President a unilateral authority to remove a Federal Judge under a democratic government? Would the ex- part Tribunal Order be enough to rely upon by the President to remove a federal judge knowing that such order is temporary and without notice to the other party in the suit? Has the President's action offended the maxim of natural justice? Thus, fair hearing in the context of section 36 of the Nigerian Constitution of 1999 encompasses the plenitude of natural justice in the narrow technical sense of the twin pillars of justice 'Nemo judex in causa sua and Audi alteram partem' (a Latin maxim meaning 'You cannot be a judge in your own cause' and 'listen to the other party' respectively) in a broad sense not only for justice to be done, but to be seen to have been done. Section 36(1) provides:

"In the determination of his civil rights and obligations, including any question or determination by or against any government or authority, a person shall be entitled to a fair hearing within a reasonable time by a court or other tribunal established by law and constituted in such manner as to secure its independence and impartiality."

An interim ex parte order is to keep matters in status quo pending the hearing of an application for an interlocutory injunction on notice to both sides. It could be argued that the ex parte order from the CCT runs counter to the letters and spirit of section 36 of the 1999 constitution and should not have been entertained. Nevertheless, could the outcome of the decision of the Tribunal been different and not lead to the removal of the CJN? Nwanguma Okechukwu of Premium Times commenting on the removal of the CJN said:

"The action subverts the constitution and the principle of Separation of powers. It undermines the Independence of the Judiciary and above all puts Nigeria's democracy in peril.... The credibility of the 2019 election will be compromised and democracy imperilled in the absence of an independent and responsive judiciary. ${ }^{139}$

The question remains whether the action of the President is within the law and for the betterment of Nigeria as an entity, or was it motivated by sectional sentiments. As a corollary, the CJN can only be removed or suspended from office either if he has been convicted or if under section 292(1) (a) (i) of the constitution Federal Republic of Nigeria 1999, the Senate affirms a request by the President to remove the CJN by two-thirds majority vote. Under S. 292 of the Nigerian Constitution, $1999,{ }^{40}$ the President's unilateral act is construed as a constitutional breach to have suspended and replaced the Chief Justice and head of the Judiciary without due consultation or support of the legislative branch of government. The President reliance on the ex parte order of the code of CCT, (an auxiliary judicial panel that addresses assets filings of public officials), to remove the CJN from

\footnotetext{
${ }^{38}$ See Okakwu (2019).

${ }^{39}$ See Ogundipe (2019).

${ }^{40}$ See the Constitution of the Federal Republic of Nigeria, 1999, as amended. Section 292 (1) (a) (i).
} 
office and appointed a replacement, Justice Ibrahim Tanko Mohammad is not in tandem with the Nigerian constitution. The CCT is an arm of the President since the judges are appointed by the President. It is unclear if an ex-parte order can be utilised to suspend and/or remove a Chief justice. The Black's Law Dictionary defines an ex parte order as: "An order made by the court upon the application of one party to act without notice to the other." ${ }^{41}$ Essentially, the Nigerian locus classicus (authority) of the concept ex parte and the principles surrounding its operation and granting of it as ex-parte orders of interim injunction was stated in the famous case of Kotoye v The Central Bank of Nigeria (1989) where Nnaemeka Agu JSC stated inter-alia:

"That by their nature injunction granted on the ex-parte application can only be interim in nature. They can be made without notice to the other side. But most importantly it must be stated that the applicant who is seeking for an interim order vide ex-parte application must disclose all materials facts pursuant to the application as the court will deal strictly with a party applying for an ex-parte order and misrepresenting facts. ${ }^{\prime 42}$

The Nigerian legal system permits a justice system that gives a fair hearing to an accused person and presumes an accused person innocent until proven guilty. This is amplified under Section 36(5) of the Nigerian Constitution, 1999 as amended which states: "Every person who is charged with a criminal offense shall be presumed to be innocent until he is proved guilty." The appointment of the CJN, President of the Court of Appeal and Chief Judge of a State and that of Federal High Court is created under Section 231 (1), 1999 Constitution of Nigeria as amended. ${ }^{43}$ The President makes the appointment on the recommendation of the National Judicial Council (NJC) subject to the Senate confirmation. In the like manner procedure, the President appoints the President of Court of Appeal as provided under section 238(1) of the 1999 constitution of Nigeria as amended. Comparatively, in the past, many Indian sitting judges have faced charges of misconduct or corruption, but none has been removed from office for the failure of one or other procedural reasons. In 1991, Justice v Ramaswami, a supreme court judge became the first judge in Independent India to face removal proceedings charged with extravagant spending on his official residences during his tenure as Chief Judge of Punjab, but no two-third majority was formed in bicameral legislatures of India in both Lok Sabha (House of the People) and Rajya Sabha (Council of States). Besides, in 2017, Nagarijuna Reddy faced a removal proceeding charged with misusing his position as High Court judge to "victimise" a Dalit judge. He was also accused of disproportionate income. Rajya Sabha members withdrew in the second attempt to remove him and the motion failed. The Indian constitution provides that a judge can only be removed by an order of the President following the motion passed by both the Lok Sabha and the Rajya Sabha based on the majority of the entire membership of the House coupled with

\footnotetext{
${ }^{41}$ See Garner (1999).

${ }^{42}$ See Koyote v CBN (1989).

${ }^{43}$ See The Constitution Federal Republic of Nigeria, Section 231 (1) as amended 199.
} 
the majority of at least two-thirds of the members of that House present and voting. ${ }^{44}$ The question is, whether the action of President Buhari on the removal of Mr. Onnoghen (CJN) could be treated as in the case of the Pakistan President, Pervez Musharraf apparent suspension and removal of the Chief justice of Supreme Court of Pakistan, Iftikhar Muhammad Chaudhry on 9 March 2007. The apparent suspension and removal of the Pakistan Chief Justice of Supreme Court by the President on allegation of misconduct erupted a mass protest, led by lawyers, which was branded Lawyer's Movement and known as the Movement for the Restoration of Judiciary or the Black Coat Protests. The Chief Justice was asked by the President to resign on allegation of misconduct but he refused and was detained under house arrest, while speedy arrangements were being made to appoint an Acting-Chief justice. The President's action was criticised by legal analysts as not only unjust or inappropriate, but unconstitutional and illegal. The Government of Pakistan made it almost impossible for a fair hearing to take its natural course in the case and many lives and properties were lost in the process of the proceedings in the Pakistan Supreme Court. Nonetheless, on 20 July 2007, the Supreme Court of Pakistan gave a verdict on the case in favour of Chief Justice Iftikhar Muhammad Chaudhry, threw out the reference filed against the CJ by President Pervez Musharraf as illegal, and unanimously reinstated the Chief Justice. ${ }^{45}$ In like manner, the incidents of then Nigerian CJN, Justice Onnoghen and the President Muhammadu Buhari of Nigeria, if such scenario is not put in check, no doubt, it will erode the long and tested sacrosanct and sanctity that follows the judiciary as the last hope of the common man. Technically, in the Nigerian Constitution, the term 'no one is above the law' exempts the President of Nigeria or Vice President, Governor, or Deputy Governor under Section 308 of the 1999 Constitution of the Federal Republic of Nigeria. Substantively, the immunity clause under Section 308 of the 1999 Constitution is provided to the President, Vice President, Governor, or Deputy Governor to give them freehand and mind in the performance of their duties to avert distraction from the multiplicity of litigations. According to Black's Law Dictionary, the term immunity means an exemption from a duty, liability, or service of process, especially such as exemption granted to a public official. ${ }^{46}$ By the same token, the Oxford Dictionary of Law defines immunity as freedom or exemption from legal proceedings. ${ }^{47}$ The immunity clause should apply to the office of the CJN, head of the judicature that upholds the supremacy of the constitution and protects the sanctity of the country's democracy. The prosecution of the CJN is in breach of public policy, contrary to the interest of the public or public welfare, and should be discouraged. Instead of public prosecution of the CJN, National Judicial Council should discipline judicial officers accused of alleged misconduct as enshrined by the constitution. This will save the government or the Country the degradation of proceedings against CJN, the country's face of the law in public prosecution by a Court of law. In

\footnotetext{
${ }^{44}$ See The Times of India (2018).

${ }^{45}$ See Chaudhry v President of Pakistan (2007).

${ }^{46}$ See Garner (1999).

${ }^{47}$ See Law (2015).
} 
Fawehinmi v. Inspector-General of Police, ${ }^{48}$ the Supreme Court of Nigeria stated that:

"The main purpose of Section 308 of the 1999 constitution is to allow an incumbent President, Vice President, Governor or Deputy Governor mentioned in that section a completely free hand and mind in the performance of the duties and responsibilities assigned to the office which he or she holds under the constitution."

It is difficult to fathom the rationale of arraigning the CJN, the head of the judicature before the Code of Conduct Tribunal or before any Court since the public policy principle protected immunity applies to the President, Senate President, or Governor of a State. It erodes the legitimacy of that immunity clause as some of the heads of the three tiers of government are left unprotected from public prosecution whilst still holding office. How relevant is this protected immunity if it is meant to pick and choose who it should apply to within the heads of the three arms of the government in the country? The rationale for the grant of the protected immunity under Section 308 of the 1999 Constitution by KaribiWhyte JSC in Tinubu v I.M.B Securities Plc. ${ }^{49}$ is to provide "a public policy principle." The public policy principle means actions anti to the interest of the public, public good, or public welfare. However, the rationale for the grant of protected immunity is two folds:- Protection for the public office and protection of the sovereignty of the State. It will amount to degradation of the office of the President or the Sovereignty of the State to drag the President or Governor of a State to Court to face examination and cross-examination in the full view of the Court. Admittedly, the CJN does not fall within the brackets of the incumbent President or the Governor of a State, but he is the head of the judicature. Dragging the CJN before the CCT will not only degrade his office but will cause embarrassment to the public who believes in the judiciary for protection and that will be contrary to public policy, Public good, the interest of the public, or public welfare. The Arraignment of the CJN before the CCT which is contrary to the public interest can be prevented by the Attorney General, the Chief Law officer of government since he has a constitutional right to do so under Section 174(3) of the 1999 Constitution of Nigeria as amended. At best, such allegation of misconduct is reserved under the Constitution for National Judicial Council (NJC) to handle as a council that disciplines judicial officers with an allegation of misconduct. ${ }^{50}$ National Judicial Council is created as Federal Executive bodies under Section 153 of the Constitution of the Federal Republic of Nigeria with the CJN as the Chairman. The Court held in Nwaogwugwu v President F.R.N (2007) ${ }^{51}$ that the NJC is a creation of the Constitution. Its primary duties are as contained in the Constitution and include amongst others, to recommend appointments or exercise disciplinary control over judicial officers. The Constitution at Section 158 (1) further provided that the NJC shall not be subject to the direction or control of any

\footnotetext{
${ }^{48}$ See Fawehinmi v Inspector-General of Police (2002) at 699-700.

${ }^{49}$ See Tinubu v I.M.B Securities Plc (2001).

${ }^{50}$ The duties and role of the NJC are provided in paragraph 21 of part One of the Third

Schedule of the 1999 Constitution of the Federal Republic of Nigeria, as amended.

${ }^{51}$ See Nwaogwugwu v President F.R.N. (2007).
} 
other authority in carrying out its power to make appointments or exercise disciplinary control over judicial officers. After all, these offenses are not of grave moral stigma or heinous acts and may be described as technical offenses and not crimes in the ordinary sense. The Privy Council held in Kariapper v Wijesinha, ${ }^{52}$ relying on the U.S. Supreme Court in the United States v Lovett (1945), and said "that the penalty imposed by law was not punishment for the criminal offense of corruption, but only disciplinary sanctions "to keep public life clean for the public good." Interestingly, in 1965 a Ceylonese legislative assembly and local government councils were convicted of corruption by a Commission of inquiry. Subsequently, the Ceylonese legislature made a new law and vacated their seats in the parliament and the local government councils and disqualified them from voting or being voted for to any office in the country for seven years. The Privy Council further said that there is a difference between a disciplinary penalty and a punishment for an offense. In support of this view, the Privy Council quoted the words of Frankfurter in the United States v Lovett (1945), ${ }^{53}$ where he said that:

"Punishment presupposes an offense, not necessarily an act previously declared criminal, but an act for which retribution is exacted. The fact that the governmental authority inflicts harm does not make it punishment [...]"

The Privy Council has shown that the CCT is formed as a disciplinary body with its powers under paragraph 18 of the Fifth Schedule of the Nigerian 1999 Constitution intended to regulate the civil, not criminal obligations or liabilities of public officers, but to discipline for non-compliance with Asset declaration. In the case of Federal Republic of Nigeria v Dr Orji Uzor Kalu, ${ }^{54}$ the former Governor of Abia State, Nigeria, Dr. Orji Uzor Kalu was arraigned before CCT on a charge of corruption, and a court in the sense of the Constitution is not just any tribunal, but one in which judicial power is vested. He pleaded the defence of immunity under Section 308 (1) of the Nigerian Constitution. The CCT held as per Justice Constance Momoh that S. 308 (1) does not apply to CCT as it is not a Court but purely a disciplinary body and lacks the power to try criminal matters; that matters before the CCT are 'sui generis' and not civil or criminal proceedings that apply to section 308 (1). A court in the sense of the Nigerian Constitution is not only a tribunal but one with vested judicial powers. ${ }^{55}$ Furthermore, the nature of CCT as a purely disciplinary body is contained in Paragraph 3(e) of the Third Schedule of the Constitution and stated that its power can only be invoked by the Criminal Conduct Bureau (CCB) complaint of non-compliance with or breach of the Code of Conduct provisions. The Nigerian Constitution under Schedule Five, paragraph 18 is intended not to punish, but to discipline and in the words of Privy Council, to 'keep public life clean for public good. ${ }^{56}$ From the foregoing, it is only appropriate that the case of the former CJN be referred to the NJC for possible

\footnotetext{
${ }^{52}$ See Kariapper v Wijesinha (1967).

${ }^{53}$ See United States v. Lovett (1945) 328 U.S.303 at 491.

${ }^{54}$ See Federal Republic of Nigeria v Dr. Orji Uzor Kalu (2006).

${ }^{55}$ See the Constitution of the Federal Republic of Nigeria (1999) as amended). Section 6 (5).

${ }^{56}$ Ibid at schedule V, Para. 18
} 
disciplinary actions. It is a bad precedent to remove the CJN in such a cavalier manner without due process bearing in mind the colossal damage this could cause in the minds of the citizens. The office of the CJN is sacred and must be guarded, respected, and protected as its impairment will derail the country's walls of justice.

\section{Recommendations}

The judiciary is the pinnacle of the legal profession. To ensure complete independence of the judiciary in Nigeria, firstly, an independent judicial appointment process should be established and called Nigerian Judicial Appointment Body (NJAB). The NJAB shall be established by the Constitution as one of the Federal Executive Bodies. ${ }^{57}$ This body shall be responsible for the recommendation, appointment, remuneration, promotion, discipline, and/or dismissal of the judicial officers in liaison with the Federal Judicial Service Commission, the Judicial Service Committee of the Federal Capital Territory, Abuja. This body shall be autonomous, autochthonous, and free from any subjugation or control from the executive arm of the government or the President in any form or manner. It does not mean that the new body will render the existing Nigerian Judicial Council (NJC) moribund, but its functions will be elaborate, firm, and independent of Presidential interference, except for checks and balances, and will work with the NJC for the restoration of the Judiciary in Nigeria. This body shall appoint the judicial officers through an electoral process participated by the citizens through a secret voting method conducted by the Independent National Electoral Commission (INEC). The implication is that these judicial officers are to serve the entire citizens of the country and have to be elected the same way the other two tiers of the government (Executive and Legislature) are elected. By so doing, the judiciary will discharge their duty without favour or fear of being removed from office arbitrarily by the ruling government if they refuse to bend due process of the law. The selection of the qualified persons to occupy the offices of the judiciary must be on merit through the countries National Judicial Council and reviewed by the NJAB. After the review, the persons selected will be screened by an independent judicial committee (IJC) that will thereafter present the successful candidates to INEC after endorsement before public voting of the citizens. This process may seem rigorous, may not have been practiced before any place in the world. Nonetheless, it is a dream for a greater future visionary, an innovation for greatness, and it is very essential for the triumph of rule of law in any country for peaceful coexistence. Any government that is not laid on a solid foundation of the rule of law is not bound to achieve an economic boom and stable governance. Secondly, the Nigerian legal system must incorporate and practice judicial review which is a critical check on the powers of the executive public body's decisions to ensure they acted within the law. Thirdly, the office of the judges should be for a lifetime as far as they satisfy the legal and ethical standards of their judicial role until retirement. Fourthly, the payment of judges should not

${ }^{57}$ Ibid, at Sec. 153 . 
be regulated by the legislative and executive branches of the government but should be from a government consolidated account. Fifthly, the judges should not be poorly paid and should be placed at the same rate of salary as the head of the executive and legislature. This will guarantee their responsibility to their families and capability to cater for their children's education to any institution they desire. It is only on such a benchmark that the government would have a moral rectitude to fight corrupt judges. I advocate for a total overhaul of the salary structure and conditions of service of judicial staff and public officers in Nigeria to equate their counterparts in developed countries. Apart from Lagos State with enhanced salaries for judicial officers, other States' salaries are poor concerning their status. That is why Justice Akanbi stated that: "Quite often, a poorly paid judge stands the risk of becoming endangered species and is likely to fall foul of the standards expected of him as a judge." ${ }^{158}$ Finally, complete independence of the Courts of justice is an essential content of the Nigerian Constitution because only an independent judiciary can impartially check an excessive exercise of power by other arms of government.

\section{Conclusion}

The ultimate aim of a society is for the law to govern, properly legally regulated and autocracy which depends on shared lies will not be on the rise. To save democracy, the truth must be prioritised over lies, tolerance over prejudice, and the Nigerian governance policy should be structured to jettison leadership by mediocrity with well-educated civilised individuals positioned into power. Democracy overtly is comprehensible where the citizens are not targeted, harassed or intimidated, detained, and/or executed because of who they are, religious beliefs, or where they come from. When the judiciary is independent, there will be clear checks and balances, and rapid economic growth. The conditions of service of the judiciary should be enhanced so that court orders are respected and implemented no matter who is involved. If the judiciary as the apex of the legal profession is respected, then democracy can still be saved with the containment of free speech, the right to life, liberty, the pursuit of happiness, and economic development in Nigeria.

\section{References}

Acholonu, P. (1995). 'Threats to the Jurisdiction of the Court and the Rule of Law in Nigeria' in All Nigeria Judges Conference Papers, pp. 43-47. Abuja: Federal Ministry of Justice.

Agunkwu, I. (2017). 'Judiciary: The Last Hope of the Common Man' in The Nigerian Lawyer, April 11. https://thenigerialawyer.com/judiciary-the-last-hope-of-thecommon-man-by-ikedi-agunkwu

\footnotetext{
${ }^{58}$ See Akanbi (1996) at 51.
} 
Akanbi M.M. (1996). 'The Many Obstacles to Justice According to Law', in 1995 All Nigerian Judges Conference Papers. Lagos: Mij Professional Publishers Ltd.

Ani, C.C. (2021). Corruption in the Criminal Justice Administration in Nigeria: The Role of the Legal Profession. Legal pedia, March 4. https://legalpediaonline.com/corruptio n-in-criminal-justice-administration-in-nigeria-2

Anifowose, R. \& F. Enemuo (1999). Elements of Politics. Lagos: Sam Iroanusi Publications.

Aristotle, (1988). The Politics (c. 350 BC). Stephen Everson (trans.), Cambridge: Cambridge University Press.

Burke, E. (1771). 'The greater the power, the more dangerous the abuse. Speech on the Middlesex Election, 7 February 1771, in The Speeches (1854) at S. Ratcliffe (ed). (2016) Oxford Essential Quotations (4ed). Oxford: Oxford University Press. DOI:10.1093/acref/9780191826719.001.0001

Dalberg-Acton, J.E.E. (1910). Lectures on the French Revolution. Edited by J. N. Figgis and R. V. Laurence. London: Macmillan and Co.

Diamond, L. (1988). Class, Ethnicity and Democracy in Nigeria: The failure of the First Republic. London: The Macmillan Press.

Egbewole,W. (2011). Jurisprudence of Election Petitions by the Nigerian Court of Appeal: Jurisprudence of Election Petitions. Lambert Academic Publishers.

Egbewole, W. (2013). 'Judex: Hope for the Hopeful and Hopeless' in the One Hundred and Thirty-Ninth $\left(139^{\text {th }}\right)$ Inaugural Lecture. University of Ilorin. Nigeria: The Library and Publications Committee University of Ilorin. Unilorin Press, Ilorin, Nigeria.

Efebeh, E.V. (2015). 'Democracy and Rule of Law in Nigeria: 1999 - 2015' in Research on Humanities and Social Sciences 5 (20):72-81.

Ferioli, E. (2015). 'Rule of Law and Constitutional Democracy' in The Turkish Year book of International Relations, 46:91-106.

Garner, B.A. (1999). Black's Law Dictionary $7^{\text {th }}$ Edition, West Group Publishing Co. USA.

Garner, B.A. \& H.C. Black (2004). Black's Law Dictionary, $8^{\text {th }}$ Ed., Thomson/West Publishing Co. USA.

Gaynor, W.J. (1903). 'A Government of Laws, Not of Men' in the North American Review 176 (55):282-286.

Gibbs. N. \& M. Duffy (2012). The Presidents Club: Inside the World's Most Exclusive Fraternity. New York: Simon \& Schuster. New York.

Handlin, O. \& M.F. Hadlin (eds.). (1966). The Popular Sources of Political Authority: Documents on the Massachusetts Constitution of 1780. Cambridge, MA: The Belknap Press of Harvard University Press.

Harden, I. \& L. Norman (1988). The Noble Lie. The British Constitution and the Rule of Law. London: Routledge.

Hayek, F.A. (1972). The Road to Serfdom. Chicago: University of Chicago Press.

Law, J. (2015). Oxford Dictionary of Law. $8^{\text {th }}$ Edition, Oxford University Press.

Locke, J. (1988). Two Treatises of Government. Ed.by P. Laslett. Cambridge: Cambridge University Press.

Mandela, N. (1990). Speech, Madison Park High School, 23 June, in Ratcliffe, Susan (2017) Oxford Essential Quotations $5^{\text {th }}$ ed. Oxford: Oxford University Press.

Ogundipe, S. (2019). 'Onnoghen: Fani-Kayode, El-Rufai, Ozekhome, others react to Suspension'. Premium Times Friday Night, 25 January. https://www.premiumtimes ng.com/news/top-news/308049-onnoghen-fani-kayode-el-rufai-ozekhome-othersreact-to-suspension.html

Okakwu , E. (2019). 'Exclusive: What CJN Onnoghen told CCB over asset declaration' Premium Times. January 12. 
https://www.premiumtimesng.com/news/headlines/305421-exclusive-what-cjnonnoghen-told-ccb-over-asset-declaration.html

Ome, E.M. (2011). "Evaluating Democracy and the Rule of law in Contemporary Nigerian society" in Bassey Andah Journal 4:95.

Onyekwere, J. \& B.C. Onochie (2019). Nigeria Judiciary in Retrospect: Vicissitudes of third arm of Government. The Guardian $8^{\text {th }}$ October. https://guardian.ng/features/ nigerias-judiciary-in-retrospect-the-vicissitudes-of-third-arm-of-government

Paine, Th. (1776). Common Sense; Addressed to the Inhabitants of America. FPP Classics.

Raz, J. (1977). 'The Rule of Law and its Virtue' in The Authority of Law. Oxford: Oxford University Press.

Sagay, I. (1996), The Travails of Democracy and the Rule of Law in Democracy and the Rule of Law. Ibadan: Spectrum Books Ltd, Nigeria, 1996.

Taylor, C. \& R. Kraut (1977). Plato's Republic. Lanham: Rowman \& Littlefield publishers.

Ten, C.I. (2017). 'Constitutionalism and the Rule of Law' in R.E. Goodin, Ph. Pettit \& T. Pogge A Companion to Contemporary Political Philosophy. John Wiley \& Sons, Ltd, pp. 493-502.

The Times of India. (2018). 6 Sitting Judges faced action, but none formally removed so far. TNN/Updated April 21. https://timesof india.indiatimes.com/india/6-sittingjudges-faced-action-but-none-formally-removed-so-far/articleshow/63852839.cms.

William, L. (2020). 'Access to Justice and the Rule of Law' in Oxford Journal of Legal Studies 40(2):377-402.

\section{Cases}

Chaudhry v The President of Pakistan (2007) PLD (SC) 578.

Fawehinmi v Inspector-General of Police, (2002) JELR 56416 (SC); 7 NWLR (Pt 727).

Federal Republic of Nigeria v Dr. Orji Uzor Kalu (2006) Charge No.

$\mathrm{CCT} / \mathrm{NC} / \mathrm{ABJ} / \mathrm{KW} / 03 / 03 / 05 / \mathrm{M}$

Kariapper v Wijesinha and an. (P.C.) [1968] A.C. 718; (1967) 3 All E.R. 485

Kotoye v C.B.N. (1989) 1 NWLR (PT. 98) 419

MacFoy v United Africa Company Limited (West Africa) [1961] UKPC 49; [1962] AC 152; [1961] 3 All ER 1169.

Nwaogwugwu v President F.R.N and others (2007) ALL FWLR (Pt 358) 1327 at 1356, para D-F (CA)

Tinubu v I.M.B Securities Plc (2001), 6 NWLR (Pt 740) 670 at 708.

United States v. Lovett (1945) 328 U.S.303.

\section{Legislation, Conventions, Charters}

The Constitution of the Federal Republic of Nigeria, [Nigeria], Act No. 24, 5 May, 1999 as amended.

United Nations. (2004). Office on Drugs and Crime, Global Action against Corruption; The Merida Papers Vienna, United Nations, p. 1 para. 1-2. 